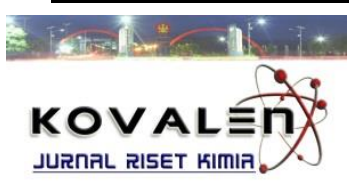

\title{
ANALISIS KANDUNGAN PROTEIN TERLARUT DAN KAROTENOID NASI JAGUNG (Zea mays var. indentata) YANG DIFERMENTASI DENGAN KAPANG ONCOM MERAH (Neurospora sp.)
}

\section{[Analysis of Dissolved Protein and Carotenoid Content of Corn Rice (Zea mays var. indentata) Fermented with Red Oncom Shells (Neurospora sp.)]}

\author{
Dwi Nurfahriani ${ }^{1}$, Nurhaeni $^{{ }^{*}}$, Khairuddin ${ }^{1}$ \\ 1) Jurusan Kimia, Fakultas MIPA, Universitas Tadulako \\ J. Soekarno Hatta, Kampus Bumi Tadulako Tondo Palu, Telp. 0451- 422611 \\ *)Corresponding Author: eni_kimia64@yahoo.co.id \\ Diterima 23 Maret 2018, Disetujui 18 Juli 2018
}

\begin{abstract}
Analysis of soluble protein and carotenoid content of maize rice (zea mays var indentata) which were fermented by red oncom (neurospora sp.). The aim of study was to determine the concentration of red oncom inoculum and fermentation time that produced corn rice with the highest levels of soluble protein and carotenoids. The study used a complete randomized design of factorial pattern consisting of two factors: a factor (inoculum concentration of red oncom mold) consisting of 3 levels including: $1 \% ; 1.5 \%$ and $2 \%$. Factor b (incubation time) consists of 3 levels: 36 hours fermentation time; 48 hours and 60 hours. The best treatment result was $2 \%$ concentration and 48 hours fermentation time with dissolved protein content $22.4 \%$ and carotenoid $0.38 \mathrm{mg}$. Fingerprint statistic analysis showed that there was no correlation between inoculum concentration and fermentation time to dissolved protein content and carotenoid content.
\end{abstract}

Keywords : corn rice, red oncom fungus, dissolved protein, carotenoids.

\begin{abstract}
ABSTRAK
Analisis kandungan protein terlarut dan karotenoid nasi jagung (zea mays var. indentata) yang difermentasi oleh kapang oncom merah (neurospora sp.). Penelitian ini bertujuan untuk mengetahui konsentrasi inokulum kapang oncom merah dan waktu fermentasi yang dapat menghasilkan nasi jagung dengan kadar protein terlarut dan karotenoid tertinggi. Penelitian menggunakan rancangan acak lengkap pola faktorial yang terdiri atas dua faktor yaitu : faktor a (konsentrasi inokulum kapang oncom merah) terdiri atas 3 taraf meliputi : 1\%; 1,5\% dan 2\%. Faktor b (waktu inkubasi) terdiri atas 3 taraf : waktu fermentasi 36 jam; 48 jam dan 60 jam. Hasil analisis diperoleh perlakuan yang terbaik adalah konsentrasi $2 \%$ dan waktu fermentasi 48 jam dengan kadar protein terlarut $22,4 \%$ dan kadar karotenoid $0,38 \mathrm{mg}$. Analisis statistic sidik ragam menunjukkan bahwa tidak terdapat korelasi antara konsentrasi inokulum dan waktu fermentasi terhadap kadar protein terlarut dan kadar karotenoid.
\end{abstract}

Kata kunci: nasi jagung, kapang oncom merah, protein terlarut, karotenoid. 


\section{LATAR BELAKANG}

Jagung merupakan salah satu bahan pokok yang terpenting di Indonesia setelah beras. Di beberapa daerah seperti di Jawa, Sulawesi dan Nusa Tenggara Timur digunakan sebagai makanan pokok utama yaitu nasi jagung (Fathonah, 1987), karena memiliki nilai gizi yang yang baik untuk tubuh seperti karbohidrat, protein, lemak dan kaya akan komponen pangan fungsional termasuk serat, mineral $(\mathrm{Ca}$, $\mathrm{Mg}, \mathrm{K}, \mathrm{Na}, \mathrm{P}$ dan $\mathrm{F}$ ), asam lemak essensial, $\beta$-karoten (provitamin A), isoflavon, asam amino esensial dan lainnya (Suarni, 2011). Jagung termasuk salah satu komoditi pangen lokal yang banyak dimanfaatkan sebagai pakan ternak, maka perlu dilakukan peningkatan kadar karotenoid dan protein pada jagung untuk meningkatkan nilai nutrisi sebagai makanan pengganti yang bernilai gizi tinggi untuk masyarakat.

Pemanfaatan jagung sebagai peningkatan gizi pada masyarakat telah dilaporkan dalam beberapa penelitian. Riandani (2013), melaporkan dalam penelitinya tentang nasi jagung instan dengan penambahan kedelai 5\% mengandung protein sebanyak $7,41 \%$. Azizah et al. (2014), melaporkan karakteritik nasi jagung instan yang disubtitusi tepung kacang hijau dengan perbandingan 55:45 mengandung kadar protein 15,40\%. Fathonah (1987), melaporkan pengaruh proses pemanasan nasi jagung terhadap kandungan protein dan lisin tersedia mengandung protein $8,28 \%$.

Nasi jagung selain memiliki kandungan protein yang baik bagi tubuh juga mengandung karotenoid yang memiliki manfaat bagi tubuh yaitu sebagai sumber vitamin $A$, meningkatkan kekebalan tubuh dan antioksidan (Artini dan Martosupono, 2009). Karotenoid dapat diproduksi menggunakan jenis kapang Neurospora crassa, Neurospora sitophila dan Neurospora intermedia yang tersimpan pada konidianya yang menyebabkan warna kuning sampai merah pada media tumbuh termasuk warna pada oncom (Gusdinar, et al., 2011). Beberapa penelitian telah memanfaatkan kapang oncom merah melalui fermentasi padat (Kenyamu, et al., 2014; Pahlevi, et al., 2008) dan fermentasi cair (Mappiratu, 1990; Nuraida, 1996).

Vilchez et al., (2011) menyatakan bahwa karotenoid merupakan pigmen yang paling umum terdapat di alam dan disintesis dalam proses fotosintesis oleh organisme termasuk kapang dan bakteri. Karotenoid diproduksi oleh kapang oncom merah melalui fermentasi padat yang berlangsung dalam substrat mengandung air yang cukup (Dharma, 1992). Menurut Kenyamu (2014) melaporkan kapang oncom merah tumbuh baik pada media tongkol jagung muda dan memproduksi pigmen karotenoid; Pahlevi et al., (2008) menyatakan kapang Neurospora $s p$ dapat tumbuh pada medium ampas tahu dan memproduksi pigmen karotenoid; 
Shojaosadati, et al., (2000), melalui penelitian tentang peningkatan kandungan protein ampas dan pati sagu melalui fermentasi padat menggunakan kapang Neurospora sitophila meningkatkan kadar protein dari $1,4 \%$ menjadi $14,45 \%$ dan $18,56 \%$ pada waktu fermentasi 48 jam. Saono (1986), kandungan protein pada tongkol jagung hasil fermentasi cukup tinggi akibat adanya pertumbuhan dan perkembangbiakan kapang Neurospora sitophila. Banerjee, et al. (1995) melaporkan batang dan daun jagung yang telah dilignifikasi dan direduksi ukurannya hingga kurang dari $1 \mathrm{~mm}$, kemudian diinokulasi dengan kapang Neurospora sitophila pada berbagai waktu inkubasi. Waktu inkubasi yang diperoleh berpengaruh terhadap kandungan protein produk fermentasi. Waktu inkubasi maksimum adalah 75 jam dan pada waktu itu, produk fermentasi mengandung protein kasar $50 \%$.

Berdasarkan latar belakang yang telah disebutkan diatas, maka dilakukan penelitian analisis kandungan protein terlarut dan karotenoid nasi jagung yang difermentasi menggunakan kapang oncom merah (Neurospora sp).

\section{METODE PENELITIAN}

\section{Bahan dan Peralatan}

Bahan utama yang digunakan dalam penelitian adalah beras jagung yang dibeli dari pasar Inpres Palu, dan inokulum kapang oncom merah (Neurospora sp). Bahan kimia yang digunakan adalah natirum hidroksida $(\mathrm{NaOH})$, aseton, heksan serta bahan lain seperti akuades, kertas saring, dan aluminium foil.

Peralatan yang digunakan dalam penelitian ini adalah neraca analitik, kompor, wajan, baskom plastik, ayakan 60 mesh, spektrofotometer Uv-Vis, reactor berpenngaduk, lemari pendingin, botol semprot, shaker.

\section{Prosedur Penelitian}

\section{Fermentasi (Modifikasi dari} Shojaosadati, S.A., 2000)

Beras jagung (1:1) ditimbang sebanyak $1 \mathrm{ksg}$, kemudian dimasak hingga matang. Nasi jagung yang telah matang didinginkan dan setelah dingin dimasukkan ke dalam gelas kimia $250 \mathrm{~mL}$ sebnyak 100 g. Nasi jagung dalam gelas kimia selanjutnya ditambahkan inokulum kapang oncom merah sesuai perlakuan (1\%, $1.5 \%$ dan $2 \%$ ), kemudian dihomogenkan dan diinkubasi dengan waktu sesuai perlakuan (36 jam, 48 jam, dan 60 jam). Nasi jagung hasil fermentasi dianalisis kadar protein dan karotenoid.

\section{Analisa Kadar Protein Terlarut (Rohman dan Sumantri, 2007)}

Sampel dari berbagai perlakuan ditimbang sebanyak $0,5 \mathrm{~g}$ kemudian dimasukkan dalam erlenmeyer $250 \mathrm{~mL}$, kemudian ditambahkan $50 \mathrm{~mL} \mathrm{NaOH} 1 \mathrm{M}$. Campuran dikocok selama 1 jam kemudian disaring dan filtratnya ditampung. Filtrat yang diperoleh kemudian diukur absorbansinya pada panjang gelombang $260 \mathrm{~nm}$ dan panjang 
gelombang $280 \mathrm{~nm}$. Kadar protein terlarut dihitung menggunakan rumus :

Kadar protein $(\%)=\frac{A_{280 \times \text { Faktor Koreksi } \times V_{\mathrm{NaOH}}} \times 100 \%}{\text { berat sampel }(\mathrm{mg})}$

Analisis Kadar Karoten (Kenyamu, et al., 2014)

Analisis karoten dilakukan menggunakan metode spektrofotometri (Mappiratu, 1990) sebagai berikut: sampel diekstrak dengan campuran pelarut heksan : aseton ( $2: 1 \mathrm{v} / \mathrm{v}$ ) diatas mesin kocok agitasi 250 rpm selama 2 jam hingga semua karoten terekstrak. Ekstrak karoten yang dihasilkan dilewatkan pada natrium sulfat anhidrat untuk membebaskan air yang terikat, kemudian diuapkan pelarutnya secara vakum menggunakan rotari vakum evaporator. Ekstrak karoten selanjutnya ditepatkan volumenya dengan menggunakan gelas ukur $50 \mathrm{ml}$ dan diukur absorbansinya pada panjang gelombang $450 \mathrm{~nm}$. Kadar karoten dapat di hitung dengan menggunakan persamaan:

$$
X=\underset{E_{1}^{1 \%} \times 100}{A \times Y}
$$

Keterangan :

$X \quad$ : berat karoten dalam gram

$A \times Y$ : nilai serapan pada $Y \mathrm{ml}$ larutan

E : koefisien serapan karotenoid (2500 $\mathrm{ml} / \mathrm{g}) \% 1 \mathrm{~cm}$

\section{HASIL DAN PEMBAHASAN}

\section{Kadar Protein Terlarut Nasi Jagung Hasil Fermentasi}

Analisis protein dalam sampel nasi jagung terdiri dari analisis protein total dan analisis protein terlarutnya. Adapun dalam penelitian ini pengukuran kadar protein terlarut dilakukan dengan menggunakan metode spektorofotometri Uv-Vis. Kombinasi konsentrasi inokulum Neurospora $s p$ dan waktu fermentasi terhadap kadar protein terlarut ditunjukkan pada Gambar 1.

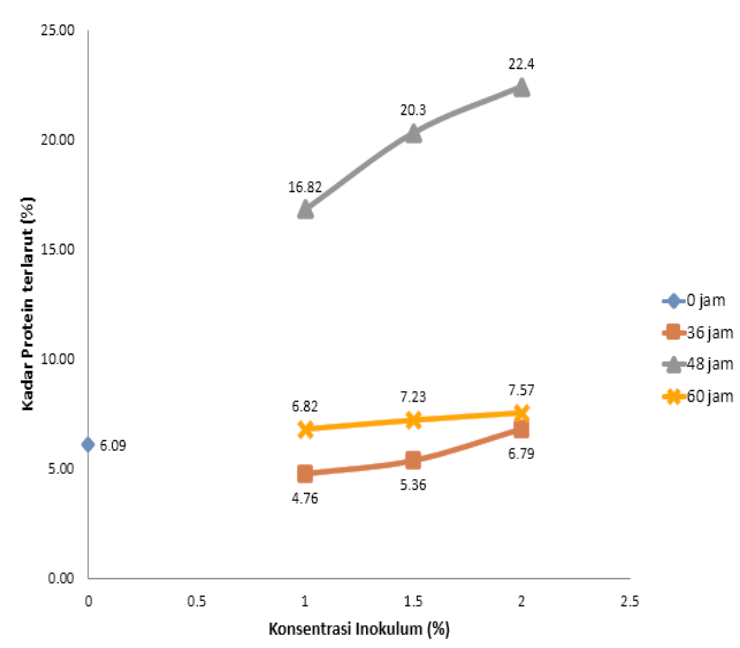

Gambar 1 Grafik Kombinasi Konsentrasi Inokulum dan Waktu Fermentasi terhadap Kadar Protein Terlarut

Hasil yang diperoleh (Gambar 1) menunjukkan bahwa kadar protein terlarut tertinggi diperoleh pada penggunaan konsentrasi inokulum $2 \%$ dan waktu fermentasi 48 yaitu sebesar 22,4\%, sedangkan kadar protein terlarut terendah terdapat pada penggunaan konsentrasi inokulum 1\% dan waktu fermentasi 36 jam yaitu sebesar 4,76\%. Rahmawanti et al. (2010), dalam penelitian kajian kandungan protein, senyawa antinutrisi, aktivitas antioksidan, dan sifat sensoris tempe koro babi (Vicia faba L.) dengan variasi pengecilan ukuran menghasilkan kadar protein terlarut sebesar $5,450 \%$ dengan lama fermentasi 48 jam. Berdasarkan dari hasil penelitian ini menyatakan bahwa 
kadar protein terlarut pada nasi jagung lebih tinggi.

Berdasarkan uji statistik untuk analisis sidik ragam pada $\alpha=0,05$ menunjukkan bahwa tidak terdapat interaksi antara konsentrasi inokulum dan waktu fermentasi terhadap kadar protein terlarut nasi jagung hasil fermentasi. Sementara untuk konsentrasi inokulum tidak berpengaruh nyata terhadap kadar protein terlarut nasi jagung hasil fermentasi. Tetapi waktu fermentasi berpengaruh nyata terhadap kadar protein terlarut nasi jagung hasil fermentasi.

Uji Duncan terhadap kadar protein terlarut tertinggi pada waktu fermentasi, menunjukan bahwa waktu fermentasi 48 jam berbeda nyata dengan waktu fermntasi 36 jam dan 60 jam. Sehingga kombinasi terpilih yang dihasilkan adalah pada waktu fermentasi 48 jam dengan kadar protein terlarut 22,4\%.

Gambar 1 menunjukkan bahwa kadar protein terlarut pada waktu fermentasi 36 jam yang lebih rendah dibandingkan dengan kontrol dikarenakan adanya proses adaptasi (phase lag) antara kapang dan sampel. Menurut Stainier et al., (1984) menyatakan bahwa fase lag (fase adaptasi) merupakan masa penyesuian sel-sel dari biakan kultur ke media yang segar mengandung kompisis kimia sebelum mampu melalui pertumbuhan.

Pada waktu fermentasi 48 jam kadar protein terlarut meningkat hal ini terjadi karena proses fermentasi aktivitas mikroba diiringi dengan pertumbuhan mikroba itu sendiri, sehingga semakin lama waktu fermentasi, maka semakin banyak jumlah mikroba dan semakin aktif kerja mikroba dalam fermentasi tersebut. $\mathrm{Hal}$ ini sesuai dengan pendapat Winarno (1993), melaporkan bahwa selama fermentasi kapang membutuhkan waktu untuk perkembangbiakan dan pertumbuhan miselia dan memanfaatkan bahan organik untuk proses degradasi metabolisme. Menurut Whittaker (1994) bahwa lama waktu fermentasi mempengaruhi terhadap hasil hidrolisis, dimana semakin banyak enzim yang bereaksi terhadap substrat sehingga protein terlarut yang di hasilkan semakin banyak.

Terjadinya penurunan kadar protein terlarut pada waktu fermentasi 60 jam disebabkan substrat habis dan aktivitas mikroba tersebut menurun. Sesuai dengan pendapat Prihastuti dan S.Yuliatun (2002), bahwa sel Neurospora sp mampu menggunakan nutrisi yang ada untuk berkembangbiak sebanyakbanyaknya pada fase logaritmik. Setelah jam ke 48 sel kapang mulai memasuki fase stasioner. Menurut Deliani (2008), semakin lama fermentasi berarti semakin lama kesempatan kapang mendegradasi protein menjadi dipeptide dan seterusnya menjadi senyawa $\mathrm{NH}_{3}$ atau $\mathrm{NH}_{2}$ yang hilang melalui penguapan, sehingga protein yang terdegradasi pun akan semakin banyak, yang mengakibatkan protein semakin menurun. 
Kadar Karotenoid Nasi Jagung Hasil Fermentasi

Hasil yang diperoleh (Gambar 2) menunjukkan bahwa kadar karotenoid tertinggi diperoleh pada konsentrasi inokulum $2 \%$ dan waktu fermentasi 48 jam yaitu sebesar 0,38 mg, kadar terendah terdapat pada konsentrasi 1\% waktu fermentasi 36 jam yaitu sebesar 0,01 mg. Hasil yang diperoleh lebih besar dibandingkan dengan kontrol yang diperoleh sebesar 0,01 mg. Hal ini terjadi karena tidak ada penambahan kapang pada sambel dan waktu fermentasi yang terlalu singkat.

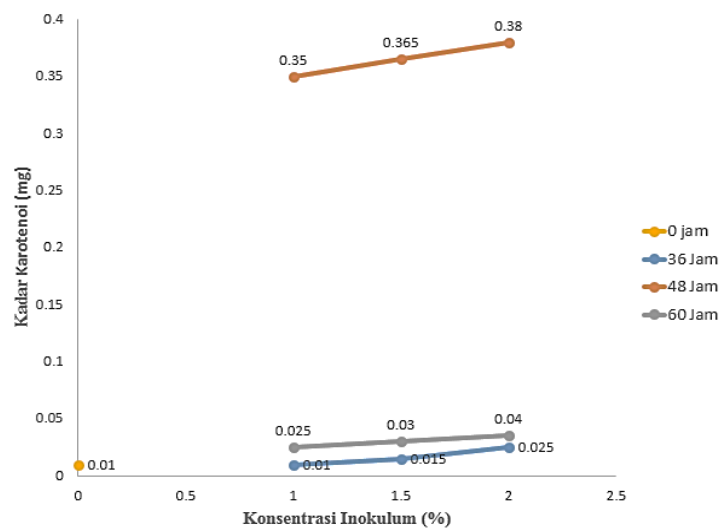

Gambar 2 Grafik kombinasi Konsentrasi Inokulum dan Waktu Fermentasi terhadap kadar Karotenoid

Berdasarkan uji statistik untuk analisis sidik ragam pada $\alpha=0,05$ menunjukkan bahwa tidak terdapat interaksi antara konsentrasi inokulum dan waktu fermentasi terhadap kadar karotenoid nasi jagung hasil fermentasi. Sementara untuk Tetapi waktu fermentasi berpengaruh nyata terhadap kadar karotenoid nasi jagung hasil fermentasi. Dilakukan analisis lanjut dengan uji
Duncan untuk menentukan kadar karotenoid tertinggi pada waktu fermentasi terpilih. Kadar karotenoid pada penggunaan waktu fermentasi pada 48 jam berbeda nyata dengan waktu fermntasi 36 jam dan 60 jam. Sehingga kombinasi terpilih yang dihasilkan adalah pada waktu fermentasi 48 jam dengan kadar karotenoid 0,38 mg.

Gambar 2 menunjukkan bahwa terjadi peningkatan kadar karotenoid mulai dari pada waktu fermentasi 36 jam hingga 48 jam, dan terjadi penurunan pada waktu fermentasi 60 jam. Hal ini terjadi karena memasuki masa pertumbuhan, nutrisi dan kandungan air pada media sudah mulai habis dan lingkungan tidak sesuai lagi untuk aktiv beraktivitas. Menurut Indarto (2010), kadar karoten menurun karena aktivitas enzim yang terdapat dalam komponen kapang berkurang sehingga akan mempengaruhi produk akhir reaksi. Pada penelitian ini proses fermentasi berlangsung secara tertutup atau dalam keadaan gelap. Menurut Renaud et al. (1976), kapang Neurospora crassa memproduksi karotenoid dengan jumlah dan komposisi yang berbeda, pada keadaan gelap dan terang, pada gelap cahaya hanya fitoena yang dihasilkan, sedangkan pada terang cahaya yang dihasilkan adalah fitofluena, 5-karoten, neurospora, likopen, $\beta$-karoten, torulena, 3,4-dehidro likopen, dan neurosporasantin. 


\section{KESIMPULAN}

Tidak terdapat pengaruh interaksi antara konsentrasi inokulum dan waktu fermentasi terhadap kadar protein terlarut dan karotenoid nasi jagung hasil fermentasi. Kadar protein terlarut nasi jagung tertinggi diperoleh pada konsentrasi inokulum $2 \%$ dan waktu fermentasi 48 jam yaitu sebesar 22,4\% dan kadar karotenoid nasi jagung tertinggi diperoleh pada konsentrasi inokulum 2\% dan waktu fermentasi 48 jam yaitu sebesar $0,38 \mathrm{mg}$.

\section{DAFTAR PUSTAKA}

Azizah, $Y \mathrm{~N}$, Dian R A, dan Dimas R A. 2014. Formulasi Dan Kajian Karakteristik Nasi Jagung (Zea Mays L) Instan Yang Disubtitusi Tepung Kacang Hijau (Phaseolus Radiatus). Jurusan Teknologi Hasil Pertanian, Fakultas Pertanian, Universitas Sebelas Maret.

Banerjee, U.C., Y. Chisti, M dan MooYoung. 1995. Effects Of Substrate Particle Size And Alkaline Pretreatment On Protein Enrichment By Neurospora Sitophila. Canada: Departement of Chemical Engineering, University of Waterloo.

Deliani. 2008. Pengaruh Lama Fermentasi terhadap Kadar Protein, Lemak, Komposisi Asam Lemak dan Asam Fitat pada Pertumbuhan Tempe. Medan: Universitas Sumatera.

Dharma. J. 1992. Pengantar Bioteknologi Pakan. Materi dan Pelatihan Bioteknologi Pakan. Bogor: BPTCiawi. hal 2.

Dwidjoseputro. 1984. Dasar-Dasar Mikrobiologi. Jakarta: Djambatan.

Indarto, A.A.D. 2010. Pengaruh Waktu Inkubasi Terhadap Kandungan Karoten Dari Kapang Oncom Merah
Pada Limbah Tongkol Jagung. Skripsi. Jurusan Kimia FMIPA. Universitas Tadulako. Palu.

Fathonah, S. 1987. Pengaruh Proses Pemasakan Nasi jagung terhadap Kandungan Protein dan Lisin Tersedia. Skripsi. Bandung: IPB.

Gusdinar T, Marlia Singgih, Sri Priatni, Sukmawati AE, Tri Suciati. 2011. Enkapsulasi dan stabilitas pigmen karotenoid dari Neurospora intermedia N-1. J Manusia dan Lingkungan.

Kenyamu, M., Mappiratu, dan Nurakhirawati. 2014. Kajian waktu Simpan Karoten Kapang Oncom Merah (Neurospora sp) yang Diproduksi pada Media Tongkol Jagung. Palu: Online Journal of Natural Science. 3(2): 62-69.

Mappiratu. 1990. Produksi Beta karoten pada Limbah Cair Tapioka dengan Kapang Oncom Merah. Tesis. Bogor : FPS Institut Pertanian Bogor.

Nuraida, L., S. H. Sihombing, dan S. Fardiaz. 1996. Produksi karotenoid pada limbah cair tahu, air kelapa dan onggok oleh kapang Neurospora sp. Buletin Teknologi dan Industri Pangan.

Pahlevi, Y.W., T. Estiasih dan E. Saparianti.2008. Microencapsulation of Carotene Extract from Neurospora Sp Sproes with Protein Based Encapsulant Using Spray Drying Method. Jurnal Teknologi Pertanian. 9(1) : 31 - 39.

Prihastuti dan S.Yuliatun. 2002. Kinetika Pertumbuhan Sel Neurospora Sitophila Pada Media Produksi Fitohormon. Pasuruan: Pusat Penelitian Perkebunan Gula Indonesia.

Rahmawanti D. A., Sri Handajani, Rohula Utami. 2010. Kajian Kandungan Protein, Senyawa Antinutrisi, Aktivitas Antioksidan, dan Sifat Sensoris Tempe Koro Babi (Vicia faba L.) dengan Variasi Pengecilan Ukuran. Surakarta: Universitas Sebelas Maret. 
Renaud, R., S. Safe, dan R. Subden. 1976. Free and Bound Lipids of Neurospora crassa. Phytochemistry. 15: 977-979.

Riandani, Mikha. 2013. Nasi Jagung Instan Berprotein Sebagai Bahan Makanan Pokok Alternative Untuk Penderita Diabetes Melitus. Semarang: Jurusan Teknik Jasa Produksi, Fakultas Teknik, Universitas Negeri Semarang.

Rohman, A dan Sumantri. 2007. Analisis Makanan. Yogyakarta: Universitas Gajah Mada.

Saono, R. 1986. Aconcise Hand Book of Indigenous Fermented Food in The Asca Countries. Indonesia: Published by The Indonesian Institute of Science (LIPI) Jakarta.

Shojaosadati, S.A., S. Vikineswary dan C.C Looi. 2000. Bioconversion and Enzymatic Activities of Neurospora Sitophila Grown Under Solid State and Submerged Fermentation on Sago dan Hampas. Iran: Biotechnology Group, Chemical Engineering Departement. Tarbiat Modarres Uviversity.

Stainer M, Mower RL, Landolfi R. 1984. Inhibition In Vitro of Platelet Aggregation And Arachidonic Acid Metabolism By Flavone. Biochem Pharmacol, 33(3):357-63

Suarni. 2011. Komposisi Nutrisi Jagung Menuju Hidup Sehat. Prosiding Seminar Nasional Serealia. Balai Penelitian Tanaman Serealia. ISBN: 978-979-8940-27-9.

Vilchez, C., Forjan, E., Cuaresma, M., Bedmar, F., Garbayo, I., \& Vega, J. M. 2011. Marine Carotenoids: Biological Function and Commercial Applications. Marine Drugs, 9: 319333.

Whittaker, J.R. 1994. Principles of Enzimology For The Food Sciences. California: Marcel Dekker Inc. 